\title{
Influence of grazing on populations of the specialist grasshopper Mioscirtus wagneri inhabiting hypersaline habitats in La Mancha Region, Central Spain
}

\author{
Maria Pilar Aguirre', Joaquín Ortego², Pedro J. Cordero'
}

1 Grupo de Investigación de la Biodiversidad Genética y Cultural, Instituto de Investigación en Recursos Cinegéticos - IREC (CSIC, UCLM, JCCM), Ronda de Toledo 12, E-13071 Ciudad Real, Spain.

2 Department of Integrative Ecology, Estación Biológica de Doñana (EBD-CSIC), Avda. Américo Vespucio 26, E-41092 Seville, Spain.

Corresponding author: Maria Pilar Aguirre (mariapilar.aguirre@uclm.es)

Academic editor: Tim Gardiner | Received 18 September 2017 | Accepted 13 December 2017 | Published 12 June 2018

http://zoobank.org/FE53A64E-4743-440D-964F-36A62ACF6F7E

Citation: Aguirre MP, Ortego J, Cordero PJ (2018) Influence of grazing on populations of the specialist grasshopper Mioscirtus wagneri inhabiting hypersaline habitats in La Mancha Region, Central Spain. Journal of Orthoptera Research 27(1): 75-81. https://doi.org/10.3897/jor.27.21064

\begin{abstract}
Grazing is an influential land use that has introduced profound changes in worldwide landscapes, ecosystems and their species. In this paper, we analysed the influence of grazing on the presence and abundance of the endangered Mioscirtus wagneri, a monophagous grasshopper inhabiting inland hypersaline ecosystems in Spain and showing a marked spatial and genetic fragmentation. Using count transects, we analyzed the presence and abundance of this grasshopper in relation to specific vegetation cover and the abundance of goat and sheep droppings, considering this variable as a surrogate of livestock activity and grazing impact. We found that both the presence and abundance of $M$. wagneri were positively related to the cover of its host plant Suaeda vera and negatively associated with the abundance of droppings. We conclude that dropping abundance is a useful parameter to assess livestock impact and evaluate habitat quality and the conservation status of M. wagneri and many other singular species of macroinvertebrates inhabiting inland hypersaline ecosystems. We highly recommend the use of electric shepherd fencing around all sensitive and protected areas where inland hypersaline ecosystems are present in order to deter livestock. We also suggest intensive educational campaigns for farmers and shepherds, revealing the ecological importance of these singular and unique habitats for rare and exclusive species like $M$. wagneri and many other coexisting plants and invertebrates.
\end{abstract}

\section{Key words}

Castilla-La Mancha, conservation, grazing management, inland hypersaline ecosystems, livestock droppings, Suaeda vera

\section{Introduction}

Historical and current grazing activities are an important influence on the landscape and, thus, on plant and animal community composition (González Bernáldez 1981, Blondel and Aronson 1999). However, intense grazing activities may alter the soil, exerting a negative impact on species biodiversity (Fleischner 1994). Intensive browsing, trampling, and resting on the ground can have a negative impact on the vegetation cover, increasing the proportion of bare soil and aggravating the effects of periods of drought
(Ledesma 2000, Gardiner and Haines 2008). However, other studies have found an opposite effect (Kisbenedek 1995, Pocco et al. 2010). In fact, grazing activities can have opposite effects on the biodiversity of both plant and animal communities depending on grazing management, intensity and the characteristics of the affected area (e.g. Rook and Tallowin 2003, Cingolani et al. 2005, Branson et al. 2006, Debano 2006, Dumont et al. 2009, Krausman et al. 2009, Báldi et al. 2013). Grazing contributes to habitat heterogeneity for Orthoptera when moderate (Fartmann et al. 2012). However, the influence of grazing on the abundance of orthopterans varies with grazing management and season (Gebeyehu and Samways 2003). Different studies have found that rotational grazing may be beneficial for orthopteran communities whereas total absence of grazing may be negative for orthopteran populations in other cases (Gebeyehu and Samways 2003, Fonderflick et al. 2014). It is worth mentioning that within a particular area, grazing may also have positive or negative effects on orthopteran populations depending on the species (Jepson-Innes and Bock 1989, Fielding and Brusven 1995, O’Neill et al. 2003).

To test the impact of grazing on grasshopper abundance, we focused on the populations of a specialist species, Mioscirtus wagneri (Kittary, 1859) (Orthoptera: Acrididae) inhabiting continental hypersaline habitats both around hypersaline lagoons and in salted ground prairies of the plant association Suadetum brevifoliae (Cirujano-Bracamonte 1981). The species feeds and obtains shelter from alkali seepweed (Suaeda vera) bushes (Cordero et al. 2007b, Ortego et al. 2010). Because of its specialized host plant dependence, we predict that grazing has a profound impact on the habitat of $M$. wagneri and provokes a significant negative effect on its populations.

Here, we aim to provide information on threats related to livestock activity on M. wagneri and its sensitive and exclusive hypersaline habitat. The aim of this study is to determine, 1) the association of M. wagneri with its host plant (S. vera, alkali seepweed) and 2) how grazing activity is related to the presence and abundance of this grasshopper in two localities, including grazed and ungrazed plots around hypersaline lagoons of La Mancha Region (Central 
Spain). To attain this, we analysed the relationship between the abundance and presence of $M$. wagneri obtained from count transects and the cover of different species of plants, the type of soil, and the abundance of livestock droppings, used as a surrogate of the intensity of livestock activity.

\section{Methods}

Study area.-The study area includes two inland salted lagoons in the center of Iberian Peninsula: Peña Hueca $\left(3^{\circ} 20^{\prime} 29^{\prime \prime} \mathrm{W}\right.$, $39^{\circ} 30^{\prime} 50^{\prime \prime} \mathrm{N}$ ) and Tirez ( $\left.3^{\circ} 21^{\prime} 27^{\prime \prime} \mathrm{W}, 39^{\circ} 32^{\prime} 21^{\prime \prime} \mathrm{N}\right)$ (Villacañas, Toledo Province, Central Spain) (Fig. 1). The lagoons present shallow waters, strong summer drought, and a high degree of salinity (Camacho et al. 2009). They constitute natural microreserves with karst sedimentation and endorheism (Peinado 1994). These lagoons are within the Biosphere Reserve of "La Mancha Wetlands" belonging to the European entity "LIC Wetlands of La Mancha" (Annex I of Directive 79/409 / EEC and Annex I and II of Directive 92/43 / EEC) (Bartolome et al. 2005). However, in spite of such a protection status, current legislation is not always adequate and livestock may graze, rest or pass through the protected areas around the lagoons. The halophilous vegetation present around these lagoons has been extensively studied (Cirujano-Bracamonte 1981 ) and is under the protection of European directives (MartínHerrero et al. 2003). Suaeda vera is one of the main plant species present in these habitats, with a woody and perennial existance on saline and hypersaline soils around inland salted lagoons (Fig. 2).
The grasshopper.-The study species is Mioscirtus wagneri, a monophagous and specialist grasshopper with a disjunct distribution and high genetic fragmentation of its populations (Cordero et al. 2007b, Ortego et al. 2009, 2010, 2011) (Fig. 3). It has been suggested that this species is particularly sensitive to habitat destruction because of its specialist nature and strong dependence on its host plant $S$. vera (Cordero et al. 2007b, Ortego et al. 2010). Mioscirtus wagneri is endangered within Western Europe (Hochkirch et al. 2016). The only populations of this species in Western Europe are found in Spain. Other grasshopper species usually accompanying M. wagneri include Aiolopus strepens (Latreille, 1804), Oedaleus decorus (Germar, 1826), Oedipoda charpentieri Fieber, 1853, Ramburiella hispanica (Rambur, 1838), Calephorus compressicornis (Latreille, 1804), Dociostaurus crassiusculus (Pantel, 1886), Dociostaurus jagoi occidentalis Soltani 1978, Calliptamus wattenwylianus (Pantel,1896), Calliptamus italicus (Linnaeus, 1758), and Sphingonotus morini (Defaut, 2005) (personal observation; see also Cordero et al. 2007b, Ortego et al. 2015).

Transects and variables.-To measure M. wagneri presence/abundance, plant species and soil type cover, we used transects in areas with different influences from grazing but within the local distribution of the grasshopper. Transects were $20 \mathrm{~m}$ in length, and $0.5 \mathrm{~m}$ on each side of the observer were surveyed (a total area of $20 \times 1 \mathrm{~m}$ per transect $=20 \mathrm{~m}^{2}$ ). On transects we collected data on M. wagneri presence and abundance, soil type, cover and species of plants and number of droppings of sheep and goats. Transects were chosen

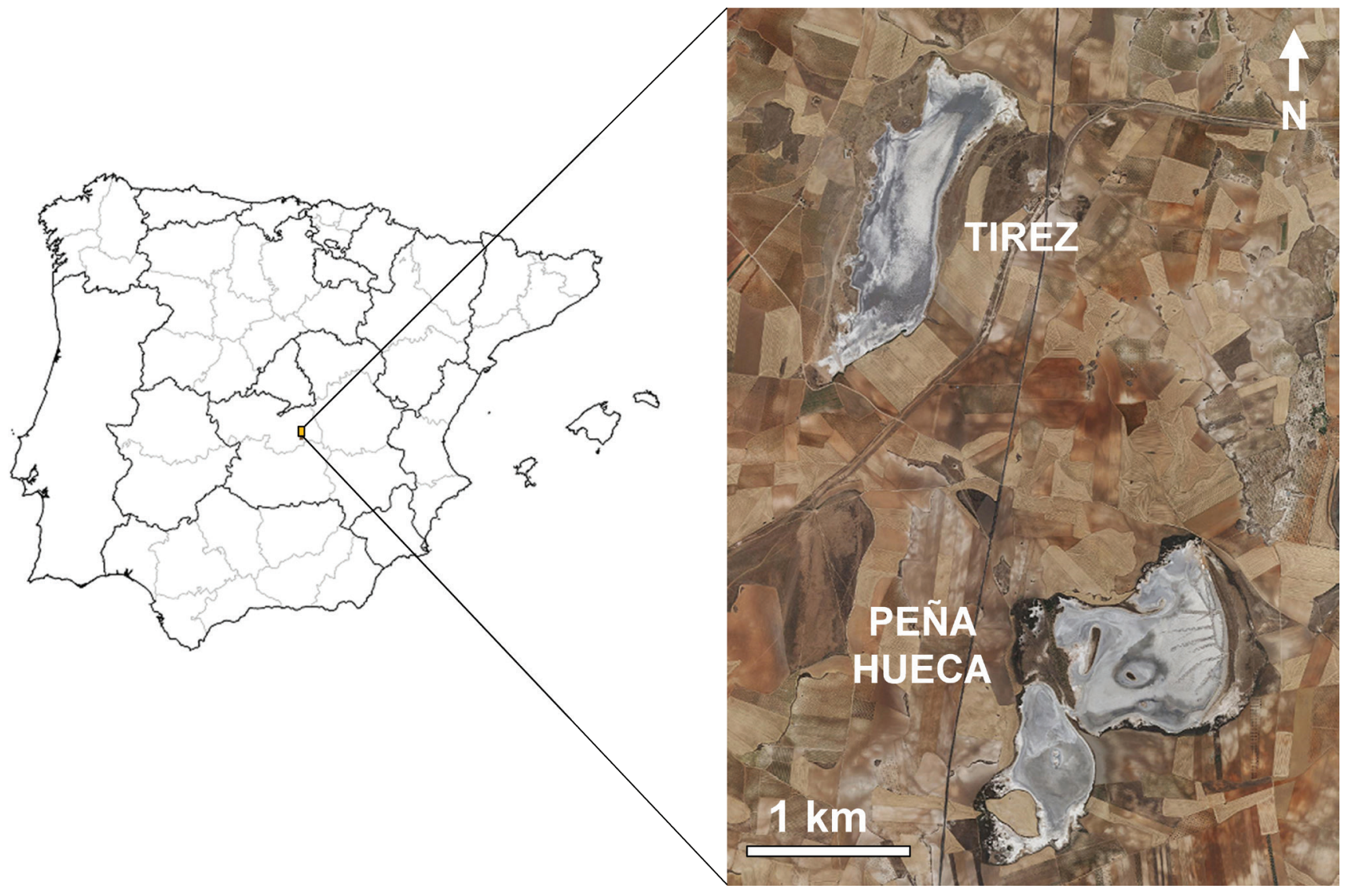

Fig. 1. Map of the study area (Villacañas, Toledo Province, Central Spain) showing the location of the hypersaline lagoons Tirez and Peña Hueca. 


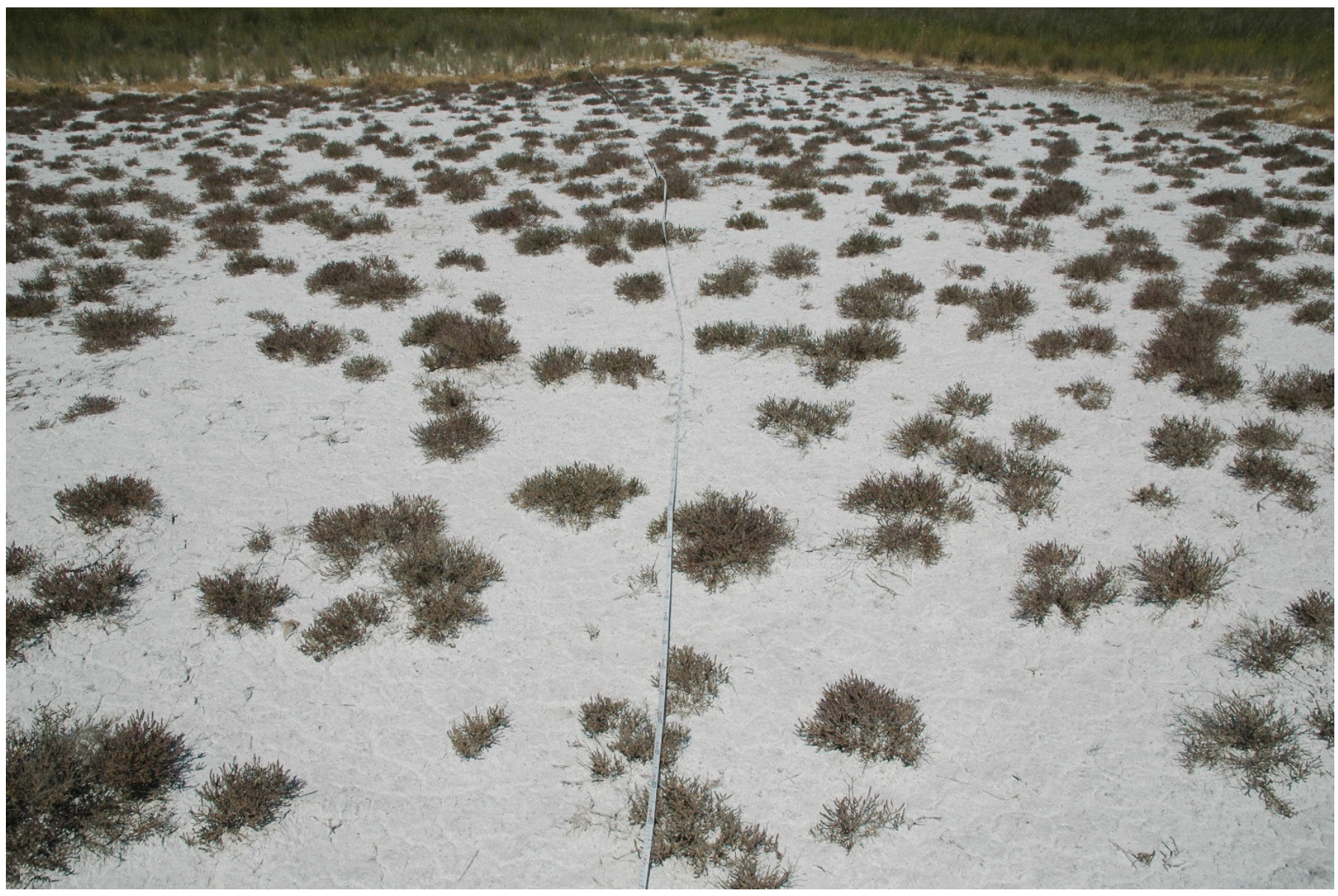

Fig. 2. Alkali seepweed prairie (Suaeda vera) without grazing, typical habitat of Mioscirtus wagneri in the study area (Peña Hueca lagoon, Villacañas, Toledo province, Spain). Photo by P.J. Cordero.

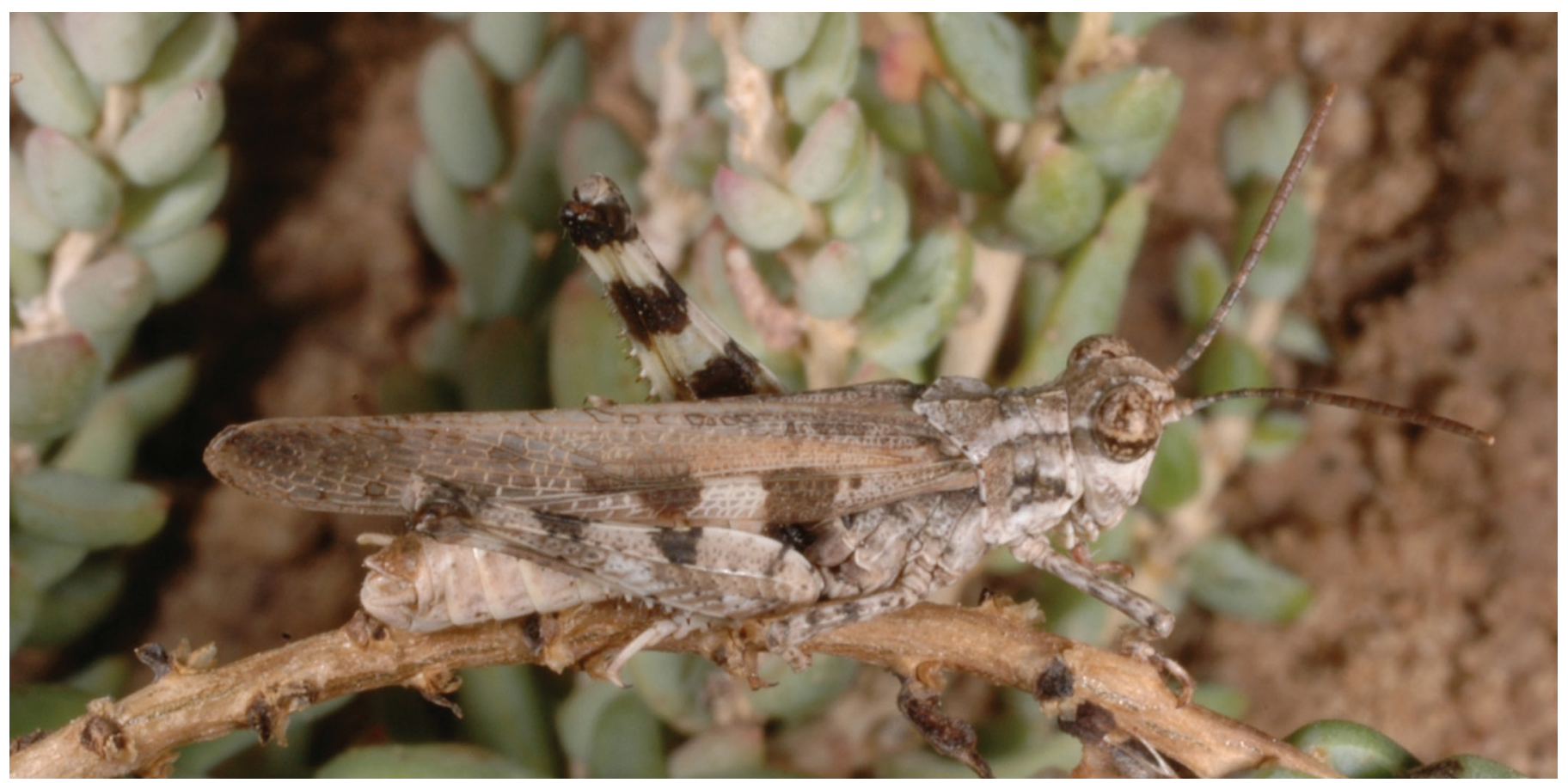

Fig. 3. Male Mioscirtus wagneri on alkali seepweed host plant, Suaeda vera. Photo by P.J. Cordero. 
taking into account the presence/absence of sheep and goat droppings and trying to include areas that have been differentially impacted by grazing. Transects were chosen at random in these areas although we tried to include those with homogeneous vegetation structure along their entire length. Grasshoppers were counted excluding possible repetitions of individuals. Transects were walked as slowly as necessary $(2 \mathrm{~km} / \mathrm{hr})$ to accurately record the presence and abundance of grasshoppers. Finally, we took pictures of each transect to check plant and soil type cover. As we previously knew the orthopteran communities in these hypersaline areas, and because of the low number of grasshoppers living in salted grounds, we only took into account censuses of M. wagneri, discarding other species for analyses. The area and orthopteran communities have been studied since 2005 (P.J. Cordero unpublished). Further, M. wagneri is easy to identify de visu due to its external appearance, color and hind wing markings. Only Aiolopus strepens could be confused with M. wagneri beyond a certain distance, but we always took into account this possibility and misidentification was minimal. Capture by hand or netting was unnecessary for identification. Our census of Orthoptera was repeatable and efficient, particularly because the species is well known in the orthopteran community and is easily identifiable (e.g. Gardiner et al. 2005).

We carried out 65 transects in Tirez and 100 transects in Peña Hueca lagoons between 10 and 17 h, during August 2009, the month in which M. wagneri is present with $100 \%$ adult forms (Cordero et al. 2007b). The data for M. wagneri along each transect is summarized by two variables: PRESENCE (presence/absence, $1 / 0$ ) and ABUNDANCE (number of individuals $/ \mathrm{m}^{2}$ ).

Three percentages of bare soil were considered: brown clay soil not affected by high salt concentration (CLAYED), hypersaline white/grey soil (SALT) and plowed land (PLOWED). Other variables included the percentage cover of the main plant associations in the area. SEEPWEED: formed by the community Suaedetum brevifoliae described above, with $S$. vera as its most abundant plant species. This small bush is scattered and rarely exceeded 70\% ground cover in the study area. It is often associated with other smaller herbaceous species such as Hordeum marinum, Puccinella fasciculata and, sometimes, Frankenia thymifolia and F. pulverulenta. HALOPHYTES: heterogeneous grassland associations belonging to halophilic communities, excluding $S$. vera, with plants such as Sarcocornia perennis, Salicornia ramosissima, Arthrocnemum coraloides, Spergularia media, Limonium spp., Plantago maritima, Suaeda maritima and some grasses such as Hordeum marinum, Polypogon maritimus, Aeluropus littoralis or Puccinellia fasciculata (maximum vegetation cover $=79 \%$ ). SALSOLA: Salsola vermiculata association. The distribution of this plant species is similar to that presented by $S$. vera, however the salinity of the soil may be lower, interspersed with various ruderal species such as Scolymus sp., Bromus sp., Centaurea sp., Chamaemelum sp., Frankenia sp., etc. (maximum vegetation cover $=80 \%$ ). ESPARTO: includes formations of Lygeum spartum (esparto grass) characterized by dense cover when it is present as the only species (maximum cover $=100 \%$ ). The accompanying species is usually Limonium sp. in moist areas. WHEATGRASS: mainly composed of Thinopyrum curvifolius (wheatgrass), of size and structural characteristics similar to ESPARTO, with high ground covering, often with Juncus sp. in small amounts (maximum vegetation cover $=80 \%$ ). HERBACEOUS: several non-halophile ruderal plants including Phragmites sp. among others (maximum vegetation cover $=85 \%$ ). STUBBLE: mown fields of wheat and barley, very close to halophile vegetation plots and rarely including any other ruderal plant species (maximum vegetation cover $=100 \%)$. DROPPINGS: number of individual cylindrical droppings of ovine-goat livestock. We assigned large clusters of faeces composed of a certain number of dropping units (5 to 10 each) according to their size. We used this variable as a surrogate of livestock influence/presence (i.e. grazing impact) and, thus, it is related to cumulative livestock presence in the area (range of droppings abundance between 0 and $7 / \mathrm{m}^{2}$ ). For analysis, we also recorded the hour (HOUR) when each transect was performed.

Statistical analyses. - We performed a forward stepwise logistic regression in order to analyze the presence of $M$. wagneri (PRESENCE, dependent or response variable) in relation to the cover of the different types of plant species (SEEWEED, HALOPHYTES, SALSOLA, ESPARTO, WHEATGRASS, HERBACEOUS, and STUBBLE), cover of the different types of bare soil (CLAYED, SALT, and PLOWED) and the number of droppings per transect (DROPPINGS). We also included in the model the hour (HOUR) and the lagoon (LAGOON) of sampling transects. To analyse the abundance of M. wagneri (ABUNDANCE), we performed a forward stepwise multiple regression considering the same independent variables as indicated above. Analyses were performed using SPSS v11 (IBM Corp. 2011).

\section{Results}

The average abundance of $M$. wagneri in transects with a presence of the species was 0.3 individuals $/ \mathrm{m}^{2}$ (range 0.05-1.3 individuals $/ \mathrm{m}^{2}$ ) We found that the presence of $M$. wagneri (PRESENCE) was positively related to the cover of $S$. vera (SEEPWEED) (Wald $=40.65, \mathrm{df}=1, P<0.0001$; Fig. $4 \mathrm{~A}$ ) but there was no significant association with any other plant community. In turn, dropping abundance (DROPPINGS), the variable indicative of grazing activity, was negatively related to the presence of the grasshopper (Wald $=8.02, \mathrm{df}=1, P=0.005$ ) (Table 1 ; Fig. 4B). Fig. 4 shows that the probability of the presence of $M$. wagneri in areas with low values of $S$. vera cover is higher without the influence of droppings. For example, at a cover of $S$. vera near $50 \%$, the probability of finding $M$. wagneri without droppings is high $(>0.9)$ whereas with a density of droppings around $7 / \mathrm{m}^{2}$ this probability falls down to 0.7 . Seemingly, the number of $M$. wagneri per square meter (ABUNDANCE) was also positively related with the cover of $S$. vera (SEEPWEED) $(F=147.67, \mathrm{df}=1, P<0.001$; Table 2 and Fig. $5 \mathrm{~A})$ and sampling time (HOUR) $(F=8.64, \mathrm{df}=1, P=0.04)$. As in the previous analysis, the abundance of $M$. wagneri was negatively associated with the variable indicative of livestock activity (DROPPINGS) ( $F=13.55, \mathrm{df}=1, P<0.001$; Table 2 and Fig. 5B).

\section{Discussion}

Our results show the dependence of $M$. wagneri on alkali seepweed formations as expected from a previous observational study (Cordero et al. 2007b). This is coincident with observations from other parts of the species distributional range like North Africa (personal observation). The species feeds and shelters on S. vera and mates and buries its oothecae in salted bare soils around the plant. This dependence on a specific microhabitat is probably the reason why $M$. wagneri is particularly sensitive to livestock activity. We found a negative relationship between the presence and abundance of $M$. wagneri in relation to the amount of sheep and goat droppings, and considered this variable as a surrogate of cumulative livestock activities in a particular area. Within the 

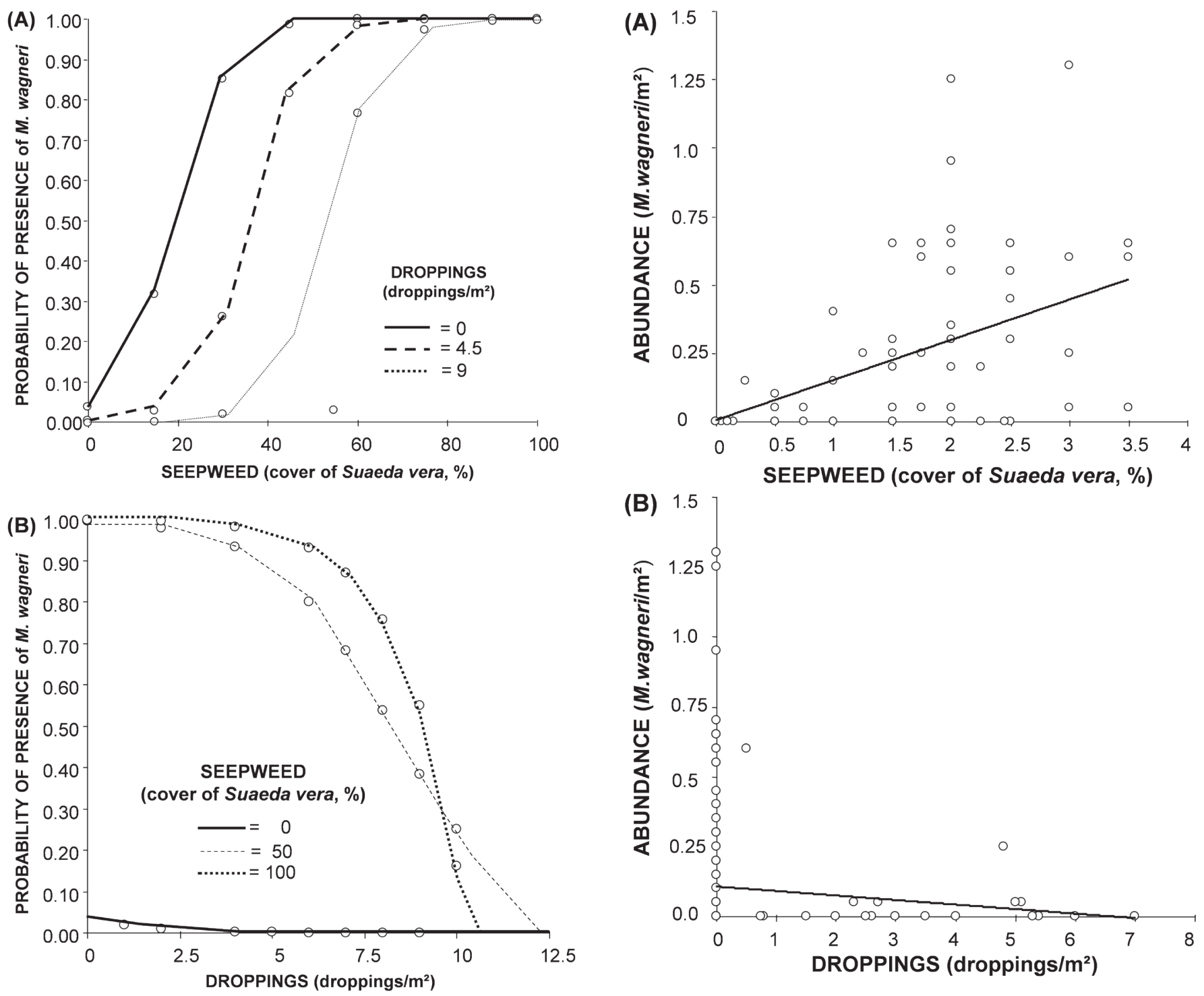

Fig. 4. Relationship between probability of presence of Mioscirtus wagneri in the transects (PRESENCE) and A. Cover (\%) of Suaeda vera (SEEPWEED) for extreme values of livestock droppings per square meter (DROPPINGS), and B. Livestock droppings per square meter (DROPPINGS) for extreme values of cover (\%) of $S$. vera (SEEPWEED).

species distributional range, our model predicts the presence and abundance of $M$. wagneri in hypersaline habitats according to different degrees of livestock impact measured as droppings/ $\mathrm{m}^{2}$. Alkali seepweed plants may coexist with livestock presence, however evident changes occur on a small scale with respect to M. wagneri microhabitat (Fig. 2). Alkali seepweed does not seem to be very palatable to sheep and goats, however, under a high concentration of droppings, plants are of lower quality with frequent defoliage and broken branches. This may occur because of livestock activities (trampling, resting over the vegetation, manure, urine or even direct browsing). Abundance of droppings and urine is frequently associated with eutrophic soils. A higher proportion of herbaceous plants like Hordeum sp. and Chenopodium sp., and

Fig. 5. Relationship between number of Mioscirtus wagneri per square meter (ABUNDANCE) and A. Cover (\%) of Suaeda vera (SEEPWEED), and B. Livestock droppings per square meter (DROPPINGS). Open circles may correspond to one or more overlapping data points.

changes in vegetation composition may increase susceptibility to predation (Joern 2004). Livestock footprints may sink a couple of centimeters into moist salted soils, compacting the ground, modifying its texture, and altering the thin layer of soil above the oothecae, which could compromise egg laying or survival.

Irrespective of the mechanisms involved in the negative relationship between the abundance of droppings and the presence and abundance of $M$. wagneri, our analyses indicate that we can use information on dropping counts as a surrogate of habitat quality for M. wagneri. Dropping counts seem to be a measurable and straightforward tool for determining the conservation status and for implementing management measures for preserving the populations of $M$. wagneri and the sensitive hypersaline habitat 
Table 1. Results of the forward stepwise logistic regression analysis for presence of Mioscirtus wagneri (PRESENCE) in relation to the different explanatory variables analyzed.

\begin{tabular}{lccc}
\hline & Estimator \pm S.E. & Wald & $P$ \\
\hline Variables included & & \\
Constant & $-3.29 \pm 0.49$ & 45.55 & $<0.001$ \\
SEEPWEED & $0.17 \pm 0.30$ & 40.65 & $<0.001$ \\
DROPPINGS & $-0.30 \pm 0.11$ & 8.02 & $<0.005$ \\
Variables excluded & & \\
HALOPHITES & & 0.100 \\
SALSOLA & 2.26 & 0.110 \\
ESPARTO & 2.56 & 0.972 \\
WEATGRASS & 0.00 & 0.996 \\
HERBACEUS & 0.00 & 0.390 \\
CLAYED & 0.74 & 0.056 \\
PLOWED & 3.65 & 0.999 \\
SALT & 0.00 & 0.199 \\
STUBBLE & 1.65 & 0.999 \\
HOUR & 0.00 & 0.225 \\
LAGOON & 1.47 & 0.801 \\
\hline
\end{tabular}

Table 2. Results of the forward stepwise multiple regression analysis for number of Mioscirtus wagneri/ $\mathrm{m}^{2}$ (ABUNDANCE) in relation to the different explanatory variables analyzed.

\begin{tabular}{lccc}
\hline & Estimator \pm S.E. & $F$ & $P$ \\
\hline Variables included & & & \\
Constant & $-4.56 \pm 1.67$ & 7.46 & $<0.007$ \\
SEEPWEED & $0.15 \pm 0.13$ & 147.67 & $<0.001$ \\
DROPPINGS & $-0.40 \pm 0.11$ & 13.55 & $<0.001$ \\
HOUR & $9.80 \pm 3.32$ & 8.64 & $<0.004$ \\
Variables excluded & & & \\
HALOPHITES & & 0.04 & 0.823 \\
SALSOLA & 0.08 & 0.782 \\
ESPARTO & 0.89 & 0.347 \\
WEATGRASS & & 0.05 & 0.817 \\
HERBACEUS & & 0.17 & 0.670 \\
CLAYED & & 2.67 & 0.104 \\
PLOWED & & 0.12 & 0.729 \\
SALT & & 0.00 & 0.988 \\
STUBBLE & & 0.14 & 0.705 \\
LAGOON & & 0.69 & 0.406 \\
\hline
\end{tabular}

where this grasshopper occurs. Dropping counts could help to improve management decisions related to compliance with legislation regarding livestock activities and habitat and species conservation. The estimate of droppings is even more important in our study if we consider that inland hypersaline habitats of M. wagneri are, by extension, shared by many macroinvertebrate species of great conservation interest within territories of high conservation concern. These include rare and fragmented taxa adapted to salinity, endemics dependent on salted soils, halophilous vegetation, or terrestrial steppic macroinvertebrates that find refuge from agriculture in these hypersaline ecosystems (Williams 1973, Ribera and Blasco-Zumeta 1998, Ribera 2000, Martín-Herrero et al. 2003, Abellán et al. 2005, Cordero et al. 2007a, Cordero and Llorente 2008, Pichaco-García and Ramos 2016).
We highly recommend the use of electric shepherd fencing around all sensitive and protected areas where inland hypersaline ecosystems are present in order to deter livestock. We also recommend intensive educational campaigns for farm owners and shepherds, showing the ecological importance of these singular and unique habitats for rare and exclusive species of plants and invertebrates.

\section{Acknowledgments}

Dragan Chobanov, Paolo Fontana and Tim Gardiner provided valuable comments on an earlier draft of this manuscript. This work received financial support from grants: POII09-0198-8057, PCI08-0130-3954 and POII10-0197-0167 (Junta de Comunidades de Castilla-La Mancha and European Social Fund), CGL201125053 and CGL2016-8742-R (Spanish Dirección General de Investigación y Gestión del Plan Nacional $\mathrm{I}+\mathrm{D}+\mathrm{i}$ and European Social Fund). JO was supported by a Ramón y Cajal (RYC-201312501) research fellowship.

\section{References}

Abellán P, Sánchez-Fernández D, Velasco-Millán A (2005) Assessing conservation priorities for insects: status of water beetles in southeast Spain. Biological Conservation 121: 79-90. https://doi.org/10.1016/j. biocon.2004.04.011

Báldi A, Batary P, Kleijn D (2013) Effects of grazing and biogeographic regions on grassland biodiversity in Hungary analysing assemblages of 1200 species. Agriculture Ecosystems and Enviromnent 166: 28-34. https://doi.org/10.1016/j.agee.2012.03.005

Bartolomé C, Álvarez Jiménez J, Vaquero J, Costa M, Casermeido MA, Giraldo J, Zamora J (2005) Los tipos de hábitat de interés comunitario en España. Madrid: Ministerio de Medio Ambiente y Medio Rural y Marino: 31, 412.

Blondel J, Aronson J (1999) Biology and Wildlife of the Mediterranean Region. Oxford University Press, Oxford, UK.

Branson DH, Joern A, Sword GA (2006) Sustainable management of insect herbivores in grassland ecosystems: New perspectives in grasshopper control. Bioscience 56: 743-755. https://doi.org/10.1641/00063568(2006)56[743:SMOIHI]2.0.CO;2

Camacho A, Chicote A, Gosálvez RU (2009) Aguas continentales retenidas. Ecosistemas leníticos de interior. In: VV. AA. Bases ecológicas preliminares para la conservación de los tipos de hábitat de interés comunitario en España, Madrid. Ministerio de Medio Ambiente, y Medio Rural y Marino 31: 412.

Cingolani AM, Noy-Meir IM, Díaz S (2005) Grazing effects on rangeland diversity: a synthesis of contemporary models. Ecological Applications 15: 757-773. https://doi.org/10.1890/03-5272

Cirujano-Bracamonte S (1981) Las lagunas manchegas y su vegetación. I, II. Anales del Jardín Botánico de Madrid 38: 187-232.

Cordero PJ, Calabuig G, Ortego J, García-Vigón E, Aparicio JM (2007a) Puntos Calientes de Biodiversidad y puntos atrayentes de Biodiversidad. In: Actas VI Convención Internacional sobre medio ambiente y desarrollo. July, 2-6 ${ }^{\text {th }}$ July, 2007. La Habana, Cuba. https://doi. org/10.3989/graellsia.2007.v63.i1.75

Cordero PJ, Llorente V, Aparicio JM (2007b) New data on morphometrics, distribution and ecology of Mioscirtus wagneri (Kittary, 1859) (Orthoptera, Acrididae) in Spain: is Maghrebi a well defined subspecies? Graellsia 63: 3-16.

Cordero PJ, Llorente V (2008) The silver-bell cricket (Orthoptera, Gryllidae), a forgotten and overlooked cricket submitted to a high risk of extinction in Western Europe. Graellsia 64: 171-180. https://doi. org/10.3989/graellsia.2008.v64.i2.30

Debano SJ (2006) Effects of livestock grazing on aboveground insect communities in semi-arid grasslands of southeastern Arizona. Biodiversity and Conservation 15: 2547-2564. https://doi.org/10.1007/ s10531-005-2786-9 
Dumont B, Farruggia A, Garel JP, Bachelard P, Boitier E, Frain M (2009) How does grazing intensity influence the diversity of plants and insects in a species-rich upland grassland on basalt soils? Grass and Forage Science 64: 92-105. https://doi.org/10.1111/j.1365-2494.2008.00674.x

Fartmann T, Krämer B, Stelzner F, Poniatowski P (2012) Orthoptera as ecological indicators for succession in steppe grassland. Ecological Indicators 20: 337-344. https://doi.org/10.1016/j.ecolind.2012.03.002

Fielding DJ, Brusven MA (1995) Grasshopper densities on grazed and ungrazed rangleland under drought conditions in southern Idaho. Great Basin Naturalist 55: 352-358.

Fleischner TL (1994) Ecological costs of livestock grazing in western North America. Conservation Biology 8: 629-644. https://doi.org/10.1046/ j.1523-1739.1994.08030629.x

Fonderflick J, Besnard A, Beuret A, Dalmais M, Schatz B (2014) The impact of grazing management on Orthoptera abundance varies over the season in Mediterranean steppe-like grassland. Acta Oecologica 60: 7-16. https://doi.org/10.1016/j.actao.2014.07.001

Gardiner T, Hill J, Chesmore D (2005) Review of the methods frequently used to estimate the abundance of orthoptera in grassland ecosystems. Journal of Insect Conservation 9: 151-173. https://doi.org/10.1007/ s10841-005-2854-1

Gardiner T, Haines K (2008) Intensive grazing by horses detrimentally affects orthopteran assemblages in floodplain grassland along the Mardyke River Valley, Essex, England. Conservation Evidence 5: 38-44.

Gebeyehu S, Samways MJ (2003) Responses of grasshopper assemblages to long-term grazing management in a semi-arid African savanna. Agriculture, Ecosystems and Environment 95: 613-622 https://doi. org/10.1016/S0167-8809(02)00178-0.

González Bernáldez F (1981) Ecología y Paisaje. Ed Blume. Madrid, 250 pp.

Hochkirch A, Nieto A, García-Criado M, Cálix M, Braud Y, Buzzetti FM, Chobanov D, Odé B, Presa Asensio JJ, Willemse L, Zuna-Kratky T, Barranco VP, Bushell M, Clemente ME, Correas JR, Dusoulier F, Ferreira S, Fontana P, García MD, Heller K-G, Iorgu IȘ, Ivković S, Kati V, Kleukers R, Krištín A, Lemonnier-Darcemont M, Lemos P, Massa B, Monnerat C, Papapavlou KP, Prunier F, Pushkar T, Roesti C, Rutschmann F, Şirin D, Skejo J, Szövényi G, Tzirkalli E, Vedenina V, Domenech JB, Barros F, Cordero Tapia PJ, Defaut B, Fartmann T, Gomboc S, Gutiérrez-Rodríguez J, Holuša J, Illich I, Karjalainen S, Kočárek P, Korsunovskaya O, Liana A, López H, Morin D, Olmo-Vidal JM, Puskás G, Savitsky V, Stalling T, Tumbrinck J (2016) European Red List of Grasshoppers, Crickets and Bush-crickets. Publications Office of the European Union, Luxembourg.

IBM corp. (2011) SPSS (v-11) IBM Corp. Released 2011. IBM SPSS Statistics for Windows, Version 20.0. IBM Corp., Armonk, NY.

Jepson-Innes K, Bock CE (1989) Response of grasshoppers (Orthoptera: Acrididae) to livestock grazing in southeastern Arizona: differences between seasons and subfamilies. Oecologia 78: 430-431. https:// doi.org/10.1007/BF00379121

Joern J (2004) Variation in grasshopper (Acrididae) densities in response to fire frequency and bison grazing in tallgrass prairie. Environmental Entomology 33: 1617-1625. https://doi.org/10.1603/0046225X-33.6.1617

Kisbenedek T (1995) The effects of sheep grazing on the community structure of grasshoppers (Orthoptera). Folia Entomologica Hungarica 56: 45-56.
Krausman PR, Naugle DE, Frisina MR, Northrup R, Bleich VC, Block WM, Wallace MC, Wright JD (2009) Livestock grazing, wildlife, habitat, and rangeland values. Rangelands 31: 15-19. https://doi. org/10.2111/1551-501X-31.5.15

Ledesma M (2000) Clímatología y Metereología Aplicada, Editorial Paraninfo.

Martín-Herrero J, Cirujano-Bracamonte S, Moreno-Pérez M, Peris-Gisbert JB, Stümbing-Martínez G (2003) La vegetación protegida en CastillaLa Mancha. JCCM - CSIC. Madrid, 375 pp.

O'Neill KM, Olson BE, Rolston MG, Wallanderb R, Larson DP, Seibert CE (2003) Effects of livestock grazing on rangeland grasshopper (Orthoptera: Acrididae) abundance. Agriculture, Ecosystems and Environment 97: 51-64. https://doi.org/10.1016/S0167-8809(03)00136-1

Ortego J, Bonal R, Cordero PJ, Aparicio JM (2009) Phylogeography of the Iberian populations of Mioscirtus wagneri (Orthoptera: Acrididae), a specialized grasshopper inhabiting highly fragmented hypersaline environments. Biological Journal of the Linnean Society 97: 623-633. https://doi.org/10.1111/j.1095-8312.2009.01206.x

Ortego J, Aguirre MP, Cordero PJ (2010) Population genetics of Mioscirtus wagneri, a grasshopper showing a highly fragmented distribution. Molecular Ecology 19: 472-483. https://doi.org/10.1111/j.1365294X.2009.04512.x

Ortego J, Aguirre MP, Cordero PJ (2011) Fine-scale spatial genetic structure and within population male-biased gene-flow in the grasshopper Mioscirtus wagneri. Evolutionary Ecology 25: 1127-1144. https://doi. org/10.1007/s10682-011-9462-1

Ortego J, García-Navas V, Noguerales V, Cordero PJ (2015) Discordant patterns of genetic and phenotypic differentiation in five grasshopper species codistributed across a microreserve network. Molecular Ecology 24: 5796-5812. https://doi.org/10.1111/mec.13426

Peinado M (1994) Funcionamiento y variabilidad de los geosistemas de los humedales manchegos. PhD thesis. Departamento de análisis geográfico regional y geografía física. Facultad de Geografía e Historia. Universidad Complutense de Madrid.

Pichaco-García P, Ramos VM (2016) Coleópteros de los humedales de Alcázar de San Juan. Tesela (Cuadernos del Ayto de Alcázar de San Juan), 66, $70 \mathrm{pp}$

Pocco ME, Damborsky MP, Cigliano MM (2010) Comunidades de Ortópteros (Insecta, Orthoptera) en pastizales del Chaco Oriental Húmedo, Argentina. Animal Biodiversity and Conservation 33: 119-129.

Ribera I, Blasco-Zumeta J (1998) Biogeographical links between steppe insects in the Monegros región (Aragón, NE Spain), the Eastern Mediterranean and Central Asia. Journal of Biogeography 25: 969-986. https://doi.org/10.1046/j.1365-2699.1998.00226.x

Ribera I (2000) Biogeography and conservation of Iberian water beetles. Biological Conservation 92: 131-150. https://doi.org/10.1016/S00063207(99)00048-8

Rook AJ, Tallowin JRB (2003) Grazing and pasture management for biodiversity benefit. Animal Researches 52: 181-189. https://doi. org/10.1051/animres:2003014

Williams RB (1973) The significance of saline lagoons as refuges for rare species. Transactions of The Norfolk and Norwich Naturalist Society Vol XXII: 387-393. 